DigitALCOMMONS @WAYNESTATE -

\section{Michigan Journal of Counseling: Research, Theory and Practice}

Volume 33 | Issue 1

Article 1

$8-1-2005$

\title{
From the Editorial Desk
}

Erin Radtka

Belleville High School

Follow this and additional works at: https://digitalcommons.wayne.edu/mijoc

\section{Recommended Citation}

Radtka, E. (2005). From the Editorial Desk, Dimensions of Counseling, 33(1), ii. doi:10.22237/mijoc/1122854400

This From the Editor is brought to you for free and open access by the Open Access Journals at DigitalCommons@WayneState. It has been accepted for inclusion in Michigan Journal of Counseling: Research, Theory and Practice by an authorized editor of DigitalCommons@WayneState. 

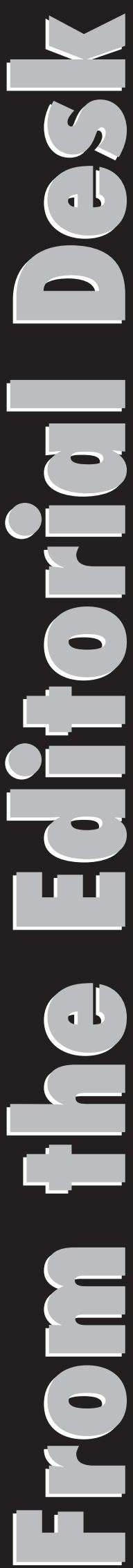

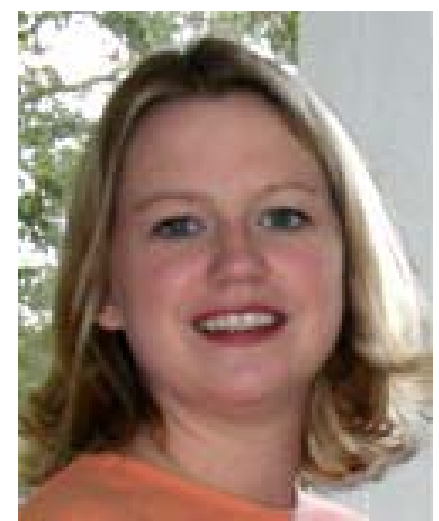

Erin Radtka, M.A., LLPC

\section{Editor}

From the Editorial Desk:

This is my first issue of the journal as sole editor, and it has been a pleasure to work with the authors and the review board to choose and polish the best of our submissions for this summer edition. All of the articles in this issue offer strong implications for the counseling profession, particularly in terms of counselor education.

Arnold Coven, Katherine Van Hull, Stacey Yaklitch, Kahdija Ali, and Jina Enwiya offer some practical active approaches for facilitating a group for persons with Traumatic Brain Injury (TBI). The article also calls for counselors to be adequately trained and prepared to counsel clients with a variety of disabilities.

The second article, submitted by Dr. Jeremy Linton, compares and contrasts a number of training models for group supervision. He offers the strengths and the limitations of these various models, and a synthesis of what would seem to work best when supervising counselors-in-training. This topic of counselor supervision is especially important as Michigan begins its requirements for the training of counselor supervisors.

Finally, Dr. Robbie Steward, Dr. Robin Powers, and Dr. Hanik Jo explore demographic and cultural factors that affect and individual's ability to express empathy. Their findings suggest that these variables need further investigation, and that interventions relating to these variables should be incorporated into counselor training programs.

Erin Radtka, M.A., LLPC, is a school counselor at Belleville High School and is the current Editor of Dimensions of Counseling: Research, Theory and Practice. 


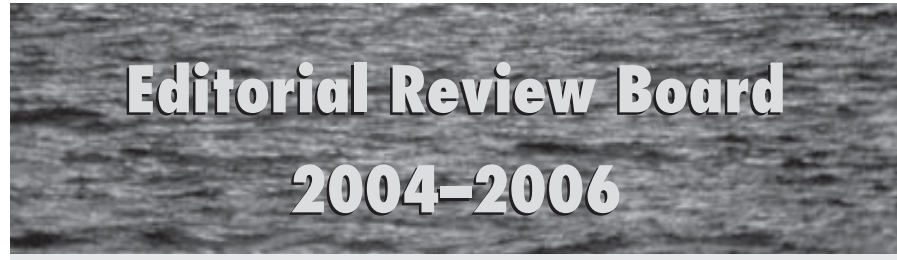

Yvonne L. Callaway, Ph.D.

Professor

Eastern Michigan University

Arnold J. Coven

Associate Professor

Wayne State University

Robert S. Fink, Ph.D.

Associate Professor

Oakland University

John Geisler, Ph.D.

Professor

Western Michigan University

Peggy Treece Myles, Ph.D.

Professor

Siena Heights University

Smita Nagpal, Ph.D

Director

Hudson Family Therapy

\section{Jina Yoon}

Assistant Professor

Wayne State University 